menstrual cycle might also affect bile lipid secretion, since the gall bladder acts both to concentrate bile and to regulate its flow into the intestine. Indeed, emptying of the gall bladder in response to injected cholecystokinin has been shown to be less during the second half of the cycle. ${ }^{25}$ Variable gall bladder function probably did not contribute to the variations in biliary cholesterol saturation which we found, since there were no significant differences in the total concentration of lipid in the bile samples (table I).

It has long been known that serum cholesterol concentrations fluctuate during the menstrual cycle. In two reports serum cholesterol concentrations were found to be highest at about ovulation, falling subsequently, ${ }^{26}: 27$ as in the present study. A cyclical fluctuation in serum triglyceride concentrations averaging more than $20^{\circ}$ ") appears to be a new finding. This is compatible with the observation of a mid-cycle peak in the concentration of very low-density lipoprotein (VLDL), the principal lipoprotein carrying endogenous triglycerides. ${ }^{2 *}$ The same workers also showed a mid-cycle peak in the concentration of high-density lipoproteins, and, since these, together with VLDL, normally contain a third to a half of the total cholesterol in serum, fluctuations in the concentrations of these lipoproteins probably account for the serum cholesterol findings.

The changes in the concentrations of lipids in serum and bile during the menstrual cycle raise the fascinating question of whether one is dependent on the other or whether both are independently related to changes in sex hormones. In view of these cyclical variations, we recommend that in any studies requiring measurements of serum and bile lipid concentrations in women of childbearing age, samples should be taken at standard points in the menstrual cycle.

Requests for reprints should be addressed to: $T S$ Low-Beer, Department of Gastroenterology, Selly Oak Hospital, Birmingham B29 6JD.

\section{References}

${ }^{1}$ Friedman, G D, Kannel, W B, and Dawber, T R, Fournal of Chronic Diseases, 1966, 19, 273.

2 Sutor, D J, and Wooley, S E, Gut, 1971, 12, 55.

${ }^{3}$ Perstemelidis, D, Panveliwalla, D, and Ahrens, E H, Gastrocnterology, 1974, 66, 565

${ }^{4}$ Bennion, L J, et al, New England fournul of Medicine, 1976, 292, 189.

${ }^{5}$ Boston Collaborative Drug Surveillance Program, Lancet, 1973, 1, 1399.

'Boston Collaborative Drug Surveillance Program, Nezi England fournal of Medicine, 1974, 290, 15

${ }^{7}$ Glenn, F, and McSherry, C K, Surgery, Gynecologv and ()bstetrics, 1968, 127, 1067

${ }^{8}$ Nestel, P J, Hirsch, E Z, and Couzens, E A, Journal of Clinical Investigation, $1965,44,891$

9 Lynn, J, et al, Annals of Surgery, 1973, 178, 514.

10 Davis, R A, and Kern, F, Gastroenterology, 1976, 70, 1130.

${ }^{11}$ Hellstöm, K, and Einarsson, K, Clinics in Gastroenterology, 1977, 6, 103.

12 British Medical fournal, 1974, 3, 132.

${ }^{13}$ Bolton, $\mathrm{C} \mathrm{H}$, et al, 1977, in preparation.

${ }^{14}$ King, E J, Biochemical fournal, 1932, 26, 292.

${ }^{15}$ Iwata, T, and Yamasaki, K, fournal of Biochemistry, 1964, 56, 424.

16 Thomas, P J, and Hofmann, A F, Gastroenterology, 1973, 65, 698.

${ }^{17}$ Hegardt, F G, and Dam, H, Zeitschrift für Ernährungswissenschaft, 1971, 10, 223

${ }^{18}$ Holzbach, R T, et al, fournal of Clinical Investigation, 1973, 52, 1467.

19 Haslewood, G A D, Murphy, G M, and Richardson, J M, Clinical Science, 1973, 44, 95.

${ }^{20}$ Macdonald, I A, Williams, C N, and Mahony, D E, Analytical Biochemistry, 1974, 57, 127.

${ }^{21}$ Hofman, A F, Journal of Lipid Research, 1962, 3, 127.

${ }^{22}$ Robertson, G, and Cramp, D G, fournal of Clinical Pathology, 1970, 23, 243.

${ }^{23}$ Kessler, G, and Lederer, H, in Automation in Analytical Chemistry, ed L T Skeggs, vol 1, p 341. New York, Mediad Inc, 1965.

${ }^{24}$ Bennion, L J, et al, New England fournal of Medicine, 1976, 294, 1187.

${ }^{25}$ Nilsson, S, and Stattin, S, Acta Chirurgica Scandinavica, 1967, 133, 648.

${ }^{26}$ Adlercreutz, H, and Tallqvist, G, Scandinavian fournal of Clinical and Laboratory Medicine, 1959, 11, 1 .

${ }^{27}$ Aldercreutz, H, Kerstell, J, and Svanborg, A, Annales Medicinae Experimentalis et Biologiae Fenniae, 1967, 45, 285 .

${ }^{2 \times}$ Barclay, M, et al, Biochemistry fournal, 1965, 96, 205.

(Accepted 6 April 1977)

\title{
Treatment of atopic eczema in children: clinical trial of 10\% sodium cromoglycate ointment
}

\author{
S A HAIDER
}

British Medical fournal, 1977, 1, 1570-1572

\section{Summary}

In a double-blind randomised group-comparative trial 21 children with chronic atopic eczema were treated twice daily for up to 12 weeks with an ointment containing $10 \%$ sodium cromoglycate (SCG) in white soft paraffin. A similar group of 21 children was treated for up to 12 weeks with a placebo ointment consisting of the white soft-paraffin base only. The number of patients who withdrew from the trial because treatment was ineffective was significantly greater in the placebo group (16) than in the SCG group (four). Comparison between the two groups also showed significant improvement in inflammation, lichenification, and cracking, and the

Bury General Hospital, Bury, Lancs BL9 6PG

S A HAIDER, MRCPE, DCH, consultant paediatrician

symptoms of itching and sleep disturbance among those on SCG treatment. At the end of treatment significantly more patients in the SCG group (16) had benefited from treatment compared with only two patients in the placebo group. No patients experienced side effects. I conclude that SCG ointment may be a safe alternative to topical steroids in the treatment of atopic eczema in children.

\section{Introduction}

Sodium cromoglycate (SCG) is effective in the treatment of asthma ${ }^{1}$ (Intal), rhinitis" (Rynacrom, Lomusol), vernal keratoconjunctivitis $^{3}$ (Opticrom), and proctocolitis. ${ }^{4}$ The drug acts by inhibiting the release of the chemical mediators of the immediate (type I) hypersensitivity reaction. Inhibition of type III reactions has also been shown in asthma. ${ }^{5}$

Eczema is a skin disorder often associated with a high incidence of atopy. ${ }^{6}$ Initial investigations ${ }^{7}$ in the treatment of a few patients with atopic eczema and contact dermatitis using up to $4 \%$ SCG, either as an aqueous solution injected intra- 
dermally or as an aqueous cream, showed no difference between SCG and control treatments. More recently encouraging results were reported after a small group of patients with chronic atopic eczema, who had failed to benefit from conventional treatment including local corticosteroids, were treated with an ointment containing 5 to $15^{\circ}$ "SCG in white soft paraffin. ${ }^{\circ}$ I decided to conduct a larger controlled study, and report here the results.

TABLE 1-Characteristics of patients in the two treatment groups on admission to trial

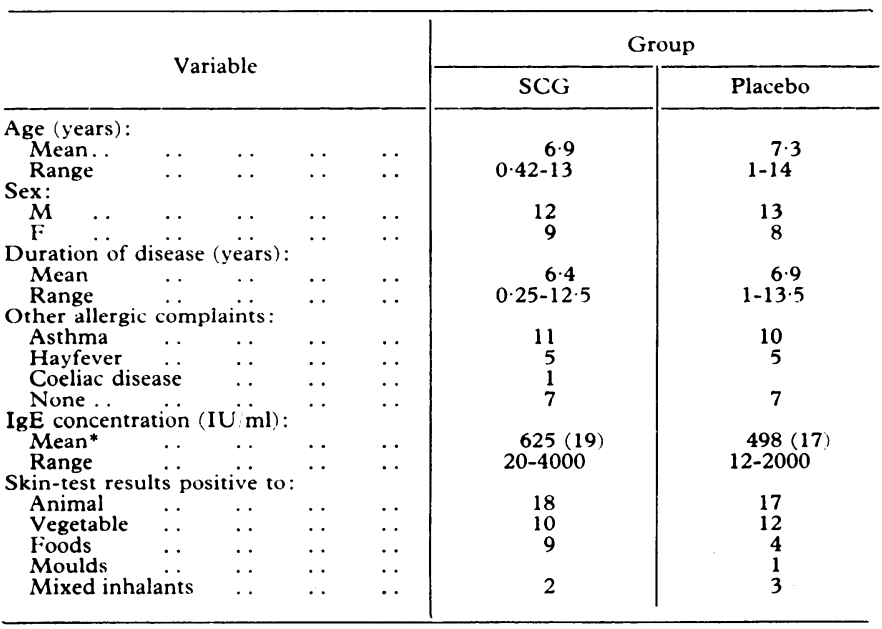

*Number of recorded readings given in parentheses.

TABLE II-Mean scores for severity of eczema (graded 0-2 in ascending order of severity) in the two treatment groups on admission to trial

\begin{tabular}{|c|c|c|c|}
\hline Sign & Area & SCG & Placebo \\
\hline $\begin{array}{l}\text { Inflammation: } \\
\text { Grade } 1-\text { Mild; erythema only . . } \\
\text { Grade } 2-\text { Moderate; erythema and }\end{array}$ & Arms & $0 \cdot 8$ & 0.5 \\
\hline 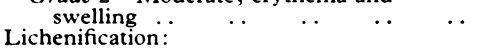 & Legs & 0.8 & 0.6 \\
\hline $\begin{array}{l}\text { Grade } 1-\text { Mild; slight increase of criss- } \\
\text { cross skin patterning } \\
\text { Grade } 2-\text { Advanced; considerable increase } \\
\text { of criss-cross skin pattern with or with- }\end{array}$ & Arms & 1.5 & 1.6 \\
\hline $\begin{array}{l}\text { out some skin thickening } \quad . \\
\text { Cracking: } \\
\text { Grade } 1 \text { - Moderate; occasional small } \\
\text { cracks } \ldots \\
\text { Grade } 2-\text { Severe; troublesome large cracks }\end{array}$ & $\begin{array}{l}\text { Arms } \\
\text { Legs }\end{array}$ & $\begin{array}{l}1 \cdot 1 \\
1.5\end{array}$ & $\begin{array}{l}1 \cdot 1 \\
1 \cdot 3\end{array}$ \\
\hline
\end{tabular}

\section{Patients and methods}

The study was designed as a double-blind group-comparative trial so that by random selection one group received the SCG ointment and the other group the placebo ointment. The duration of treatment for each group was 12 weeks. A total of 44 children were entered in the trial, but two did not return for subsequent assessment. The final analysis was therefore based on 21 children in each treatment group.

Each of the participants was diagnosed as having chronic atopic eczema on the basis of characteristic skin lesions, and one or more of the following signs: a history of atopic disease; a positive skin-test result to one or more allergens; and a high serum IgE concentration $(400 \mathrm{IU} / \mathrm{ml})$. All patients had been treated with topical steroids, either alone or in combination with other drugs. All topical treatment was, however, discontinued for two weeks before the start of the trial.

The two treatment groups were similar at admission with respect to mean age and duration of disease, sex distribution, presence of other allergic diseases, mean serum IgE concentrations, and skin-test results (table I). I assessed the severity of inflammation, lichenification, and cracking at the beginning of the study and at frequent intervals thereafter. These signs were assessed on a scale 0-2 for four areas of the body-face, trunk, arms, and legs. Because the severity of eczema on the face and trunk was minimal, only the changes in signs on the arms and legs were subsequently analysed. The severity of the signs on the arms and legs at admission (table II) was similar for the two treatment groups.

Each child or parent completed a daily diary card on which were recorded the severity of itching during the day and night, and the degree of sleep disturbance. Scores were graded 0-3 in ascending order of severity.

Sleep scores-sound sleep, no disturbance (0); some difficulty in going to sleep, no disturbance during the night (1); difficulty in going to sleep, disturbed once or twice during the night (2); great difficulty in going to sleep, disturbed many times during the night (3).

Itching scores-no itching (0); mild, only aware of itching at times (1); moderate, often aware of itching, annoying (2); severe, constant itching, distressing (3).

The SCG ointment contained $10 \%$ SCG in a white soft-paraffin base; the placebo ointment contained the base only. The ointments were applied to eczematous lesions night and morning. No other topical treatment was used during the trial.

Statistical testing was conducted at the two-tail 5\% level, using $\chi^{2}$ and Mann-Whitney $U$ tests.

\section{Results and comment}

Many patients withdrew from the trial before the end of the 12 week period because their treatment was ineffective. Significantly more patients in the placebo group (16) compared with the SCG group (four) withdrew for this reason $(P<0.001)$.

The differences between the mean scores assigned at the end of each week of treatment and at admission for each group are shown in

TABLE III-Differences between mean scores for severity of clinical signs at the end of each week for the two treatment groups, and individual variation between mean scores in last week of treatment

\begin{tabular}{|c|c|c|c|c|c|c|c|}
\hline \multirow{2}{*}{ Week } & \multirow{2}{*}{ Group } & \multicolumn{2}{|c|}{ Inflammation } & \multicolumn{2}{|c|}{ Lichenification } & \multicolumn{2}{|c|}{ Cracking } \\
\hline & & Arms & Legs & Arms & Legs & Arms & Legs \\
\hline 1 & $\begin{array}{l}\text { SCG }(n=12) \\
\text { Placebo }(n=14) \\
\text { Significance }\end{array}$ & $\begin{array}{l}0.2 \\
0.6 \\
\text { NS }\end{array}$ & $\begin{array}{l}0.2 \\
0.4 \\
\text { NS }\end{array}$ & $\begin{array}{r}-0.1 \\
\text { NS }\end{array}$ & $\begin{array}{c}-0.1 \\
\text { NS }\end{array}$ & NS & NS \\
\hline 2 & $\begin{array}{l}\operatorname{SCG}(n=15) \\
\text { Placebo }(n=12) \\
\text { Significance }\end{array}$ & $\begin{array}{l}0.3 \\
0.5 \\
\text { NS }\end{array}$ & $\begin{array}{l}0.3 \\
0.5 \\
\text { NS }\end{array}$ & NS & NS & $\begin{array}{r}-0 \cdot 1 \\
\text { NS }\end{array}$ & $\begin{array}{l}0 \cdot 1 \\
\text { NS }\end{array}$ \\
\hline 3 & $\begin{array}{l}\text { SCG }(n=10) \\
\text { Placebo }(n=9) \\
\text { Significance }\end{array}$ & $\begin{array}{l}0.2 \\
0 \cdot 4 \\
\text { NS }\end{array}$ & $\begin{array}{l}0 \cdot 2 \\
0 \cdot 4 \\
\text { NS }\end{array}$ & $\begin{array}{r}-0.2 \\
\text { NS }\end{array}$ & NS & $\begin{array}{r}-0.1 \\
0.1 \\
N S\end{array}$ & $\begin{array}{r}-0 \cdot 2 \\
\text { NS }\end{array}$ \\
\hline 4 & $\begin{array}{l}\operatorname{SCG}(n=13) \\
\text { Placebo }(n=8) \\
\text { Significance }\end{array}$ & $\begin{array}{l}-0.4 \\
1.2 \\
P<0.01\end{array}$ & $\begin{array}{l}-0.4 \\
1.2 \\
P<0.01\end{array}$ & $\begin{array}{r}-0 \cdot 1 \\
-0.1 \\
\text { NS }\end{array}$ & $\begin{array}{r}-0 \cdot 2 \\
\text { NS }\end{array}$ & $\begin{array}{r}-0.3 \\
0 \cdot 1 \\
\text { NS }\end{array}$ & $\begin{array}{r}-0 \cdot 1 \\
\text { NS }\end{array}$ \\
\hline 5 & $\begin{array}{l}\operatorname{SCG}(n=6) \\
\text { Placebo }(n=5) \\
\text { Significance }\end{array}$ & $\begin{array}{c}-0.7 \\
0.8 \\
P<0.01\end{array}$ & $\begin{array}{c}-0.7 \\
0.8 \\
P<0.01\end{array}$ & NS & $\begin{array}{r}-0.2 \\
\text { NS }\end{array}$ & $\begin{array}{r}-0.7 \\
0.2 \\
\text { NS }\end{array}$ & $\begin{array}{r}-0.5 \\
0 \cdot 2 \\
\text { NS }\end{array}$ \\
\hline Last & $\begin{array}{l}\operatorname{SCG}(n=21) \\
\text { Placebo }(n=21) \\
\text { Significance }\end{array}$ & $\begin{array}{l}-0.6 \\
0.8 \\
P<0.01\end{array}$ & $\begin{array}{l}-0.5 \\
0.7 \\
P<0.01\end{array}$ & $\begin{array}{l}-0.9 \\
-0.1 \\
P<0.01\end{array}$ & $\begin{array}{l}-0.8 \\
-0.1 \\
P<0.01\end{array}$ & $\begin{array}{c}-0.9 \\
0.1 \\
P<0.01\end{array}$ & $\begin{array}{l}-1.2 \\
-0.1 \\
\mathbf{P}<0.01\end{array}$ \\
\hline
\end{tabular}

Significance calculated by means of Mann-Whitney $U$ test

$\mathrm{NS}=$ not significant $(\mathrm{P}>0 \cdot 05)$. 
table III. The difference between the SCG and placebo groups is significant by week 4 for inflammation and by the last week of treatment for lichenification and cracking also. Comparisons could not be made after week 5 because sample sizes in the placebo group became too small as patients left the trial. Nevertheless, the variation between patients in mean scores during the last week of treatment were compared to assess the final effect of treatment in all patients.

The mean weekly scores from the diary cards (table IV) show that patients in the SCG group consistently improved week by week, while those in the placebo group experienced either no overall improvement or deteriorated slightly. In the SCG group both the sleep pattern and itching at night had significantly improved by week 3 , and itching by day was significantly reduced by week 4 . These improvements were maintained during the last week of treatment.

TABLE JV-Mean total weekly scores for sleep and itching recorded by patients in the two treatment groups

\begin{tabular}{|c|c|c|c|c|}
\hline \multirow{2}{*}{ Week } & \multirow{2}{*}{ Group } & \multicolumn{2}{|c|}{ Itching } & \multirow{2}{*}{ Sleep } \\
\hline & & Day & Night & \\
\hline 1 & $\begin{array}{l}\text { SCG }(n=21) \\
\text { Placebo }(n=19) \\
\text { Significance }\end{array}$ & $\begin{array}{l}11 \cdot 2 \\
10 \cdot 4 \\
\text { NS }\end{array}$ & $\begin{array}{l}10 \cdot 2 \\
10 \cdot 7 \\
\text { NS }\end{array}$ & $\begin{array}{c}7 \cdot 4 \\
8 \cdot 8 \\
\text { NS }\end{array}$ \\
\hline 2 & $\begin{array}{l}\operatorname{SCG}(n=19) \\
\text { Placebo }(n=12) \\
\text { Significance }\end{array}$ & $\begin{array}{l}9 \cdot 3 \\
12 \cdot 2 \\
\mathrm{NS}\end{array}$ & $\begin{array}{l}9 \cdot 1 \\
11 \cdot 1 \\
\text { NS }\end{array}$ & $\begin{array}{l}7 \cdot 3 \\
10 \cdot 2 \\
\text { NS }\end{array}$ \\
\hline 3 & $\begin{array}{l}\text { SCG }(n=19) \\
\text { Placebo }(n=12) \\
\text { Significance }\end{array}$ & $\begin{array}{l}8.5 \\
11 \cdot 2 \\
\text { NS }\end{array}$ & $\begin{array}{c}8.0 \\
11.4 \\
P<0.05\end{array}$ & $\begin{array}{c}5 \cdot 8 \\
10 \cdot 1 \\
\mathrm{P}<0 \cdot 01\end{array}$ \\
\hline 4 & $\begin{array}{l}\operatorname{SCG}(n=18) \\
\text { Placebo }(n=9) \\
\text { Significance }\end{array}$ & $\begin{array}{c}6.1 \\
12 \cdot 3 \\
\mathrm{P}<0.01\end{array}$ & $\begin{array}{c}6.5 \\
13.1 \\
\mathrm{P}<0.01\end{array}$ & $\begin{array}{c}3.9 \\
9.5 \\
P<0.01\end{array}$ \\
\hline 5 & $\begin{array}{l}\text { SCG }(n=18) \\
\text { Placebo }(n=8) \\
\text { Significance }\end{array}$ & $\begin{array}{c}6.8 \\
12 \cdot 1 \\
P<0.01\end{array}$ & $\begin{array}{c}6.0 \\
11.9 \\
P<0.01\end{array}$ & $\begin{array}{c}2.9 \\
8.1 \\
P<0.01\end{array}$ \\
\hline Last & $\begin{array}{l}\text { SCG }(n=21) \\
\text { Placebo }(n=20) \\
\text { Significance. }\end{array}$ & $\begin{array}{c}4.6 \\
11.4 \\
P<0.01\end{array}$ & $\begin{array}{c}4.6 \\
12 \cdot 1 \\
\mathrm{P}<0.01\end{array}$ & $\begin{array}{c}2.7 \\
\quad 9.8 \\
\mathrm{P}<0.01\end{array}$ \\
\hline
\end{tabular}

Significance calculated by means of Mann-Whitney $U$ test.

NS $=$ not significant $(\mathbf{P}>0.05)$.

Itching scores recorded on following scale: $0=$ none; $1=$ mild, only aware of itching Itching scores recorded on following scale: $0=$ none; $1=$ mild, only aware of itching
sometimes; $2=$ moderate, often aware of itching, annoying; $3=$ severe, constant
itching, distressing.

Sleep scores recorded on following scale: $0=$ sound, no disturbance; $1=$ difficulty in going to sleep, but no disturbance during night; $2=$ difficulty in going to sleep disturbed once or twice during night; 3 = great difficulty in going to sleep, disturbed often during night.

Final assessments of changes in disease state on the affected limbs were made by me and by the patient (or parent). The results from these four assessments were identical: 16 patients benefited from treatment with the SCG ointment and only two from the placebo ointment. This difference is highly significant $(P<0.001)$. No patients suffered side effects from either treatment.

\section{Discussion}

This study shows that SCG is effective in the treatment of atopic eczema in children. There have been no reports of the value of topical SCG for atopic skin lesions. Studies of the effect of SCG on immediate hypersensitivity in skin have shown inhibition of histamine release from sensitised rat skin in vitro $^{9}$ and in vivo, ${ }^{10}$ although no consistent inhibition by SCG of histamine release from sensitised human skin in vitro"1 was observed. Pilot studies" of SCG as a solution and as an aqueous cream also failed to show any inhibition of type I responses in the skin of a few atopic patients, perhaps because the concentration used (up to $4{ }^{\prime \prime}{ }_{0}$ ) was too low.

In the present study SCG had a significant antipruritic effect. Pruritus is the basic symptom of atopic eczema. The reason for the itch is not clearly understood, but it probably constitutes the initial change, the epidermal reaction being secondary. The antipruritic effect of SCG may be important in breaking the vicious circle of itching followed by scratching and inflammation, thereby preventing inflammatory and ensuing chronic changes.

All the children were maintained on treatment with SCG ointment after completion of the trial. In three children SCG treatment was discontinued; two had outgrown atopic eczema and required no further treatment, and the third ceased to benefit from it. In others the eczema reappeared when topical SCG treatment was stopped. Frequency of treatment ranged from twice daily to application on alternate days.

The lack of side effects of SCG treatment in this trial is consistent with the established reputation of SCG as a drug with a low order of toxicity. In view of the side effects often associated with topical steroid treatment, the results of this trial have identified a possible safe alternative treatment for atopic dermatoses. Further studies of the effect of SCG on atopic eczema are clearly required. These may help to clarify the pathogenesis of itch in atopic eczema, and also the mode of action of SCG in skin.

\section{References}

1 Brogden, R N, Speight, T M, and Avery, G S, Drugs, 1974, 7, 164.

${ }^{2}$ Brogden, R N, Speight, T M, and Avery, G S, Drugs, 1974, 7, 283.

3 Easty, D L, Rice, N S C, and Jones, B R, Clinical Allergy, 1972, 2, 99.

${ }^{4}$ Mani, V, et al, Lancet, 1976, 1, 439.

5 Brogden, R N, Speight, T M, and Avery, G S, Drugs, 1974, 7, 196.

${ }^{6}$ Champion, R H, and Parish, W E, in Clinical Aspects of Immunology, ed P G H Gell, R R A Coombs, and P J Lachmann, 3rd edn, p 1183. Oxford, Blackwell, 1975 .

' Fisons Limited, Pharmaceutical Division, unpublished data.

${ }^{8}$ Haider, S A, unpublished data.

9 Greaves, M W, Fairley, V M, and Yamamoto, S, International Archives of Allergy and Applied Immunology, 1971, 41, 932

10 Goose, J, and Blair, A M J N, Immunology, 1969, 16, 749.

11 Pearce, C A, et al, Clinical and Experimental Immunology, 1974, 17, 437.

(Accepted 6 April 1977) 